University of Nebraska - Lincoln

DigitalCommons@University of Nebraska - Lincoln

Potential Effects of Changes in Temperature and Food Resources on Life History Trajectories of Juvenile Oncorhynchus mykiss

Joseph R. Benjamin

U.S. Geological Survey, jbenjamin@usgs.gov

Patrick J. Connolly

U.S. Geological Survey

Jason G. Romine

U.S. Geological Survey

Russell W. Perry

U.S. Geological Survey

Follow this and additional works at: https://digitalcommons.unl.edu/usgsstaffpub

Benjamin, Joseph R.; Connolly, Patrick J.; Romine, Jason G.; and Perry, Russell W., "Potential Effects of Changes in Temperature and Food Resources on Life History Trajectories of Juvenile Oncorhynchus mykiss" (2013). USGS Staff -- Published Research. 700.

https://digitalcommons.unl.edu/usgsstaffpub/700

This Article is brought to you for free and open access by the US Geological Survey at DigitalCommons@University of Nebraska - Lincoln. It has been accepted for inclusion in USGS Staff -- Published Research by an authorized administrator of DigitalCommons@University of Nebraska - Lincoln. 


\title{
Potential Effects of Changes in Temperature and Food Resources on Life History Trajectories of Juvenile Oncorhynchus mykiss
}

\author{
Joseph R. Benjamin,* Patrick J. Connolly, Jason G. Romine, and Russell W. Perry \\ U.S. Geological Survey, Western Fisheries Research Center, Columbia River Research Laboratory, \\ 5501a Cook-Underwood Road, Cook, Washington 98605, USA
}

\begin{abstract}
Increasing temperatures and changes in food resources owing to climate change may alter the growth and migratory behavior of organisms. This is particularly important for salmonid species like Oncorhynchus mykiss, where some individuals remain in freshwater to mature (nonanadromous Rainbow Trout) and others migrate to sea (anadromous Steelhead). Whether one strategy is adopted over the other may depend on the individual's growth and size. In this study, we explored (1) how water temperature in Beaver Creek, a tributary to the Methow River, Washington, may increase under four climate scenarios, (2) how these thermal changes may alter the life history trajectory followed by $O$. mykiss (i.e., when and if to smolt), and (3) how changes in food quality or quantity might interact with increasing temperatures. We combined bioenergetic and state-dependent life history models parameterized for $O$. mykiss in Beaver Creek to mimic baseline life history trajectories. Based on our simulations, when mean water temperature was increased by $0.6^{\circ} \mathrm{C}$ there was a reduction in life history diversity and a $57 \%$ increase in the number of individuals becoming smolts. When mean temperature was increased by $2.7^{\circ} \mathrm{C}$, it resulted in $87 \%$ fewer smolts than in the baseline and fewer life history trajectories expressed. A reduction in food resources led to slower growth, more life history trajectories, and a greater proportion of smolts. In contrast, when food resources were increased, fish grew faster, which reduced the proportion of smolts and life history diversity. Our modeling suggests that warmer water temperatures associated with climate change could decrease the life history diversity of $O$. mykiss in the central portion of their range and thereby reduce resiliency to other disturbances. In addition, changes in food resources could mediate or exacerbate the effect of water temperature on the life history trajectories of $O$. mykiss.
\end{abstract}

Rising temperatures associated with global climate change are apparent (IPCC 2007) and can alter an organism's physiology, ecology, and behavior. Examples include increased growth rate and earlier maturation of plants and animals (Nemani et al. 2003; Pörtner and Farrell 2008), and earlier onset of migration in birds, butterflies, and fishes (Roy and Sparks 2000; Cotton 2003; Jonsson and Jonsson 2009). However, the consequences of warming temperatures on growth, maturation, and migratory behavior may not be mutually exclusive because age at maturation or migration is often associated with the size of the individual (Pörtner and Farrell 2008). For instance, in aquatic ecosystems where most fish are ectothermic, those in warmer waters tend to grow faster and, in turn, mature or migrate at younger ages than those in colder waters (Brander 2007; Jonsson and Jonsson 2009). Thus, increasing water temperatures linked to climate change can increase growth rates and advance development of fish unless thermal tolerances are exceeded, in which case growth may decline.

In addition to water temperatures directly controlling the rates of growth and development of fish by altering metabolism, temperature can indirectly control these processes via changes in food resources (Beauchamp 2009). For example, warming temperatures have been linked to a decline in the abundance and size of aquatic macroinvertebrates (Durance and Ormerod 2007; Daufresne et al. 2009). This, in turn, can reduce the growth of fish by reducing the quantity (abundance), quality (size), or

*Corresponding author: jbenjamin@usgs.gov

Received January 9, 2012; accepted September 4, 2012

Published online December 21, 2012 
both of aquatic macroinvertebrate prey. Furthermore, changes in temperature might shift aquatic macroinvertebrate life history timing relative to that of some fish species, which may also impact food availability (Harper and Peckarsky 2006). Alternatively, as temperatures rise, primary production of streams may increase, subsequently increasing the prey resources and fish growth (Woodward et al. 2010). Regardless of the mechanism, changes in growth and development have been linked to changes in fish migratory behavior, especially those that undergo longdistance migrations (Jonsson and Jonsson 2009). For example, recent studies have observed a decrease in age at migration and earlier migration timing of Chinook Salmon Oncorhynchus tshawytscha in response to environmental conditions, including increased water temperature (Achord et al. 2007; Crozier et al. 2008a). However, these studies have been for those salmon in which most or all individuals migrate to sea.

Some salmonid species display partial migration, where populations may be divided into anadromous and nonanadromous individuals (Jonsson and Jonsson 1993; Thorpe et al. 1998). In such populations, offspring may adopt an anadromous or nonanadromous life history despite their parentage (Christie et al. 2011), suggesting that juveniles maintain sufficient phenotypic plasticity to adopt either life history strategy (Zimmerman and Reeves 2000). For fish species exhibiting partial migration, juvenile freshwater residents are likely to have lower metabolic costs, higher lipid content, and increased growth rates, which often leads to larger size relative to similarly aged anadromous conspecifics (Jonsson and Jonsson 1993, 2009; Thorpe et al. 1998; Morinville and Rasmussen 2003). Furthermore, anadromous individuals that migrate to richer feeding areas may exhibit increased growth and size, which is related to fitness via fecundity and survival (Jonsson and Jonsson 1993). Hence, whether an individual adopts a life history to migrate to sea may be influenced by its growth and size, which, in turn, are influenced by the environment. However, few studies have explored the consequences of environmental drivers, such as water temperature or food resources, on the distribution of life history strategies in populations exhibiting partial migration.

Among salmonid fishes, O. mykiss (Steelhead and Rainbow Trout) display partial migration that, in part, can be attributed to environmental factors (Thorpe 2007). Juveniles may spend 1-7 years in freshwater (Peven et al. 1994) before adopting either an anadromous (migrating to sea as smolts to become Steelhead) or nonanadromous (sexually maturing in freshwater to become Rainbow Trout) life history strategy. Hence, following Thorpe (2007), there are 14 possible life history trajectories for juveniles. We define a life history trajectory as a combination of age and pathway taken (i.e., to smolt as a Steelhead or mature in freshwater as a Rainbow Trout). Despite a diversity of potential trajectories, relatively little research has been conducted to project which pathway will be followed. However, it is likely that thermal conditions and food resources are important (Olsson et al. 2006; McMillan et al. 2012). Recently, a statedependent model was used to predict life history trajectories for juvenile $O$. mykiss in central California streams by Satterthwaite et al. $(2009,2010)$ based on survival, fecundity, and growth. We modified this model to simulate how environmental changes may alter the distribution of life history trajectories adopted by O. mykiss in a stream in northern Washington.

Here, we explore the relationship between warming temperatures and changes in food resources owing to climate change and the potential changes in life history trajectories of $O$. mykiss. We simulated the growth of female fish and their life history trajectory under different climate scenarios using a combination of bioenergetic (Hanson et al. 1997) and state-dependent life history (Satterthwaite et al. 2009) models (Figure 1). We focused on female fish because they tend to migrate more frequently and typically exhibit greater fitness with size than males (Jonsson and Jonsson 1993; Satterthwaite et al. 2009). We expected that their growth would increase with temperature and thus maturing as a Rainbow Trout or smolting as a Steelhead would occur at an earlier age, which would reduce the diversity of life history trajectories. In addition, we explored the consequences of warming temperatures and changes in food quality or quantity on the growth of $O$. mykiss and the proportion of the juvenile population adopting the anadromous versus nonanadromous pathway.

\section{METHODS}

Study site.-To simulate potential effects of warming temperature owing to climate change on growth and life history of juvenile $O$. mykiss, we focused on a population of Rainbow Trout and Steelhead in the lower portion of Beaver Creek, a tributary of the Methow River, Washington. In this section, Beaver Creek is a third-order stream at low elevation (463-548 m) and relatively small in wetted width $(4.6 \pm 0.2 \mathrm{~m}$ [mean $\pm \mathrm{SE}])$ and discharge at base flow $\left(0.05 \mathrm{~m}^{3} / \mathrm{s}\right.$; Martens and Connolly 2010). The Steelhead population in the Methow River basin is supported by hatchery releases of smolts (Berejikian et al. 2012), but in Beaver Creek the population is largely from natural spawning O. mykiss. Although O. mykiss is the dominant fish species, other fish present in Beaver Creek include Chinook Salmon, Brook Trout Salvelinus fontinalis, and Shorthead Sculpin Cottus confusus (Martens and Connolly 2010).

The life history trajectory and dispersal of juvenile $O$. mykiss in Beaver Creek has been investigated by tagging these fish with PIT tags. Passive integrated transponder tags were used to detect fish movement via instream antennas known as PIT tag interrogation systems (river kilometer [rkm] 3.5 in Beaver Creek), and some were captured at a weir near the mouth of Beaver Creek (rkm 1; Connolly et al. 2008; Martens and Connolly 2010). For juvenile Steelhead, we have observed three life history trajectories; the majority will smolt at age 2 or $3(66 \%$ and $30 \%$, respectively), with some ( $\sim \%)$ age- 4 smolts being observed (P. J. Connolly, unpublished data). However, it is possible that some of these fish simply moved out of Beaver Creek and into the Methow River. We are unsure of the ratio of the population of $O$. mykiss that becomes Steelhead to those that remain in 


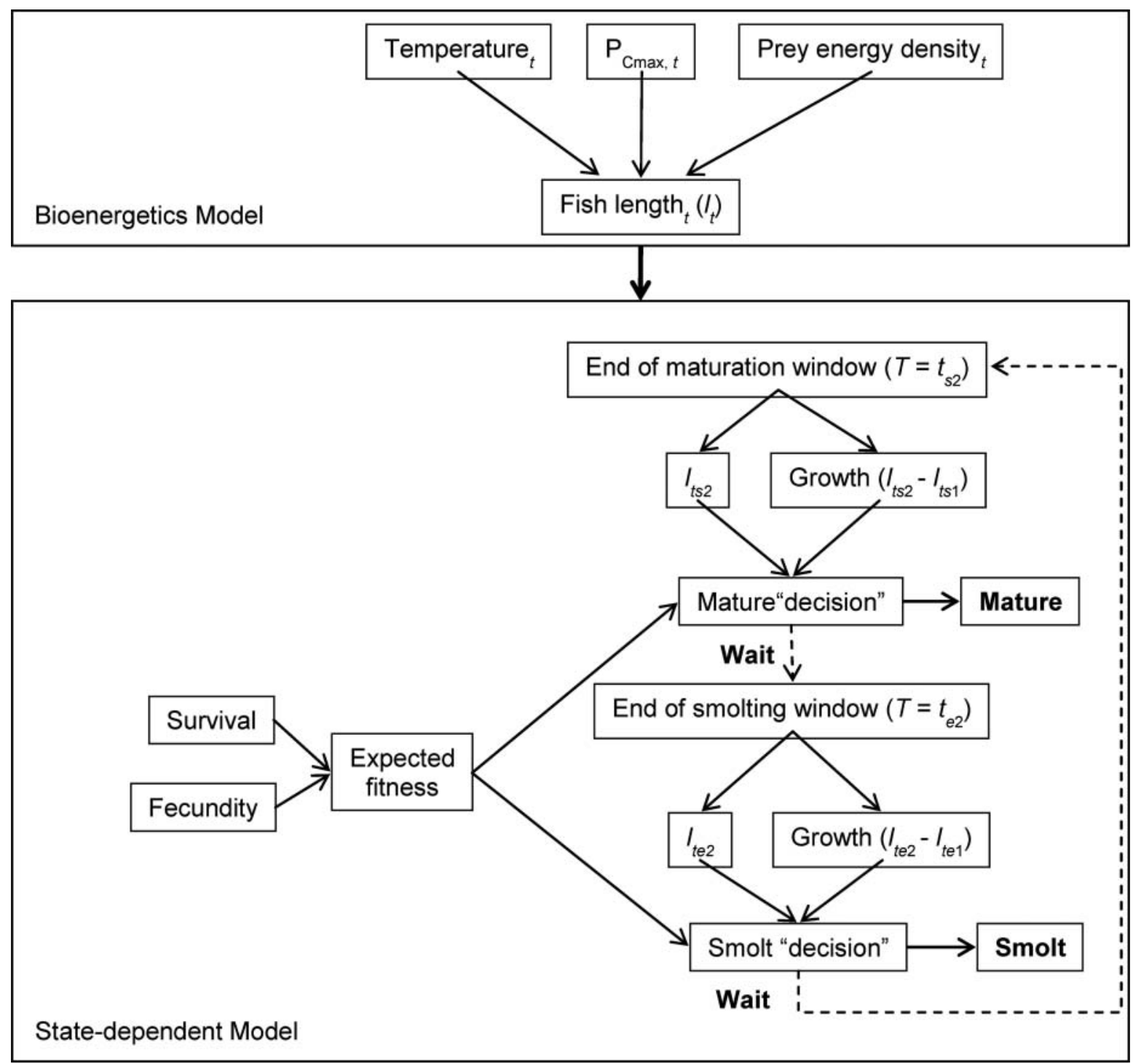

FIGURE 1. Conceptual diagram of the linkages between the climate change scenarios (i.e., temperature, $P_{C m a x}$, and prey energy density), the bioenergetics model, and the state-dependent life history model. The bioenergetics model simulates the length of each fish $(l)$ at time $t$. The state-dependent model then predicts life history trajectories to either mature and spawn as a Rainbow Trout $(s)$ or emigrate as a Steelhead smolt $(e)$ as a function of expected fitness, growth over discrete time windows ( $t_{s 1}$ to $t_{s 2}$ or $t_{e 1}$ to $t_{e 2}$ ), and the length at the end of the window. The dashed line indicates no trajectory has been adopted and individual fish loop through the model until a trajectory is followed. See text for more details.

freshwater as Rainbow Trout. We assumed nonanadromous Rainbow Trout mature anywhere from age 1 to 4 , but the distribution of age at maturation is unknown.

Temperature and climate change scenarios.-To simulate daily water temperatures in Beaver Creek, we first used a nonlinear regression model to estimate weekly average water temperatures from weekly average air as described in Mohseni et al. (1998). This model assumes that the relationship between air and water temperature will incorporate factors that influence water temperature (e.g., shading, hydrology, atmospheric conditions). We sampled daily water temperature (Stowaway Tidbit; Onset, Pocasset, Massachusetts) in Beaver Creek every 30-60 min from 25 October 2005 to 23 April 2007, 27 March 2009 to 17 March 2010, and 13 July to 31 December 2010. Continuous average daily air temperature recorded at a weather station near the mouth of the Methow River (latitude $=48^{\circ} 8^{\prime}$, longitude $=$ $120^{\circ} 3^{\prime}$, elevation $=357 \mathrm{~m}$ ) was obtained from the National Oceanic and Atmospheric Administration (NOAA) National Climate Data Center (http://www.ncdc.noaa.gov/oa/ncdc.html).

Given the estimated parameters of the regression model, we then predicted daily water temperature using a 7-d moving average of air temperature. We considered an estimate of daily water temperature from a weekly average air temperature to be an appropriate measure because water temperature does not 
change instantaneously with air temperature but lags behind (Mohseni and Stefan 1999). In addition, water temperature summarized as a 7-d moving average may be more appropriate to estimate fish growth and behavior because fish are likely to find refuge to avoid temporary peaks in temperature but less likely to avoid prolonged peaks (Eaton and Scheller 1996). The air-to-water temperature model for Beaver Creek had a good fit based on the Nash-Sutcliffe coefficient (NSC; Nash and Sutcliffe 1970 as cited in Mohseni et al. 1998; NSC = 0.94 [perfect fit $=1.0]$ ). This model was treated as the baseline model to which water temperature increases under the climate change scenarios were compared.

Because of the uncertainty in predicting increases in temperature over the next seven decades, we simulated seasonal changes in stream temperature under four climate change scenarios. We used an average seasonal temperature increase under the A1B $(n=10)$ and B1 $(n=9)$ climate change scenarios for future greenhouse gas emissions in the Pacific Northwest (Mote and Salathé 2010). These can be considered medium (A1B) and low (B1) warming scenarios with an average annual increase in air temperature of $1.2^{\circ} \mathrm{C}$ by the $2020 \mathrm{~s}$ (scenario 1 ), $1.9^{\circ} \mathrm{C}$ by the 2040 s (scenario 2 ), and $3.1^{\circ} \mathrm{C}$ by the 2080 s (scenario 3; see Table 1 for seasonal temperature increases). In addition, we estimated water temperature increases based on Mote and Salathé's (2010) most extreme predicted warming of air temperature, $5.6^{\circ} \mathrm{C}$, by 2080 (scenario 4). Under each scenario, we added the respective seasonal increase in air temperature to the baseline 7-d moving average of air temperature and modeled the respective increase in daily water temperature for years 2005-2010. We then averaged daily water temperature across the 6 years to develop the average annual temperature cycle of Beaver Creek.

Bioenergetics and life history models.-We used a modified version of the Wisconsin bioenergetics model (Hanson et al. 1997), parameterized for O. mykiss (Thornton and Lessem 1978; Railsback and Rose 1999), to explore the effects of increasing temperature projected under climate change on the growth of juvenile O. mykiss (Figure 1). Growth rates under the bioenergetics model were determined based on physiology, water temperature, food availability or quality, and individual variability (i.e., emergence size and daily consumption). The average daily water temperature as derived above was used for the baseline and climate scenarios to grow fish in the bioenergetics model. We used the same daily water temperature for each year the fish grew, ending when a fish either emigrated as a smolt or spawned as a mature freshwater resident (see below).

We simulated 2,000 age- 0 fry with an average start size of $55 \mathrm{~mm}(\mathrm{SD}=7.16)$ drawn from a normal distribution and start date of August 1, corresponding to field observations. We assumed the variation in starting size on a given date captures the variation in size expected from differences in date of fry emergence. The proportion of maximum consumption $\left(P_{C \max }=0.34 \pm 0.10\right.$ [mean $\pm \mathrm{SD}$ ] $)$ was estimated by fitting the bioenergetics model to observed growth of markedrecaptured juvenile fish in Beaver Creek $(n=128)$. We structured the model to randomly assign a different daily $P_{C \max }$ for each fish $(n=1,700)$, drawn from the normal distribution (mean $=0.34 ; \mathrm{SD}=0.10)$. However, this did not account for individuals adopting a trajectory at age 4 , as observed in our empirical data. Thus, for 300 fish, we randomly assigned daily $P_{C \max }$ of $0.30 \pm 0.09$ (mean $\pm \mathrm{SD}$ ), which was within the range of values $(0.20-0.50)$ estimated from recaptured fish. Diets of juvenile $O$. mykiss in the Methow River basin were assumed to be $75 \%$ aquatic and $25 \%$ terrestrial insects (energy density $=2,800 \mathrm{~J} / \mathrm{g}$ and $5,000 \mathrm{~J} / \mathrm{g}$, respectively; Beauchamp 2009) from April to October, and $95 \%$ aquatic and $5 \%$ terrestrial from November to March (Bellmore 2011).

Specific growth estimates from the bioenergetics model during key timing events of a fish's life were fit into a statedependent life history model developed by Satterthwaite et al. (2009) to project the trajectory of $O$. mykiss to smolt and migrate to the ocean or to mature without going to the sea (Figure 1). We based the timing of events on field observations and previously published literature for the area. These included an average

TABLE 1. The average seasonal increase in air temperature projected under the baseline and four climate scenarios, and corresponding mean (SE) water temperatures for Beaver Creek. In addition, the estimated shifts in the mean emergence day and mean date that age- 0 O. mykiss reach 55-mm FL. The winter season includes the months December, January, and February; spring includes March, April, and May; summer includes June, July, and August; and fall includes September, October, and November.

\begin{tabular}{|c|c|c|c|c|c|c|c|c|c|c|c|}
\hline \multirow[b]{2}{*}{ Scenario } & \multicolumn{4}{|c|}{ Increases in air temperature $\left({ }^{\circ} \mathrm{C}\right)$} & \multicolumn{7}{|c|}{ Mean water temperature $\left({ }^{\circ} \mathrm{C}\right)$} \\
\hline & Winter & Spring & Summer & Fall & Winter & Spring & Summer & Fall & Annual & $\begin{array}{l}\text { Emergence } \\
\text { day }\end{array}$ & $\begin{array}{c}\text { Day } \\
\text { 55-mm FL } \\
\text { achieved }\end{array}$ \\
\hline Baseline & & & & & $1.0(0.03)$ & $5.4(0.24)$ & $12.7(0.17)$ & $6.0(0.38)$ & $6.3(0.25)$ & 15 Jun & 1 Aug \\
\hline 1 & 1.1 & 1.0 & 1.5 & 1.0 & $1.2(0.04)$ & $6.0(0.26)$ & $13.7(0.15)$ & $6.5(0.40)$ & $6.9(0.26)$ & 12 Jun & $26 \mathrm{Jul}$ \\
\hline 2 & 1.8 & 1.6 & 2.3 & 1.8 & $1.4(0.04)$ & $6.4(0.27)$ & $14.1(0.15)$ & $7.0(0.41)$ & $7.2(0.27)$ & 10 Jun & $23 \mathrm{Jul}$ \\
\hline 3 & 3.0 & 2.5 & 3.8 & 2.9 & $1.6(0.05)$ & $6.9(0.27)$ & $14.9(0.13)$ & $7.6(0.42)$ & $7.8(0.28)$ & 7 Jun & $18 \mathrm{Jul}$ \\
\hline 4 & 5.1 & 5.4 & 6.9 & 4.8 & $2.2(0.06)$ & $8.9(0.29)$ & $16.2(0.10)$ & $8.7(0.44)$ & $9.0(0.29)$ & 3 Jun & $12 \mathrm{Jul}$ \\
\hline
\end{tabular}


spawning date (May 1), an average date when fry emerge from the gravel (June 15), an average date when smolts emigrate (June 1; Peven et al. 1994; Snow et al. 2008), and discrete segments of time when smoltification or maturation are initiated (described below). The life history model evaluates which potential life history trajectory will provide the greatest fitness based on the growth and size of a fish during a "decision window." For this model, fitness is defined as a combination of size-dependent egg production and survival; thus, the trajectories are estimated for female fish only. Decision windows were assumed to be fixed periods in time where physiological, morphological, and behavioral changes may begin depending on the growth and size of the fish (Thorpe et al. 1998; Satterthwaite et al. 2009). For smolting, we assumed the window was between October 1 and December 31 , approximately 6 months prior to emigration. The window for maturing fish, May 1-June 1, was assumed to occur approximately 1 year before spawning because sexual maturation likely involves a greater physiological investment than smolting. This window, however, occurs prior to emergence, which would preclude age- 0 fish from becoming sexually mature at age 1 . To negate this, age-1 maturation was based on growth from date of emergence (i.e., June 15) to October 1.

In addition to timing events and growth through a juvenile fish's life, the life history model estimates fitness based on survival, fecundity, and the maximum size achievable in freshwater (Satterthwaite et al. 2009). No data were available for egg-toemergence survival rates within the Methow River basin, so we estimated it to be $6.5 \%$ based on a coastal Steelhead population in southwest British Columbia (Ward and Slaney 1993). The remaining freshwater annual survival rates were assumed to be $50 \%$, which is within the range of survival rates of other $\mathrm{On}$ corhynchus spp. throughout the Columbia River basin (Bradford 1995) and provided similar proportions of smolts we observed in the field. Length-dependent, smolt-to-adult return survival, $\sigma(l)$, was determined from the release of 50,000 hatchery fish in the Methow River (Gale et al. 2009) and estimated as

$$
\sigma(l)=0.36 \frac{e^{-6.171+0.03843 l}}{1+e^{-6.171+0.03843 l}},
$$

using a Cormack-Jolly-Seber mark-recapture model in $\mathrm{R}(\mathrm{R}$ Development Core Team 2011). The ocean survival rate of $36 \%$ was suggested by Ward et al. (1989) for Steelhead smolts emigrating at $230 \mathrm{~mm}$, which is consistent with the largest smolts from the Methow River (Peven et al. 1994). Length-specific fecundity of nonanadromous female Rainbow Trout, $\phi(l)$ was estimated from Hodge (2010) for O. mykiss in the Klamath River basin as

$$
\phi(l)=0.2128 * l^{2.4301}
$$

An average lifetime fecundity of anadromous females was estimated at 5,545 based on returns of wild Steelhead to Wells Dam from 2000 to 2006 (Snow et al. 2008). Although a small percentage of Steelhead spawn multiple times, we considered the contribution of repeat spawning events to be negligible and thus only one spawning event was considered in the fitness estimation. Rainbow Trout in Beaver Creek can achieve a maximum size of approximately $400 \mathrm{~mm}$ (Connolly, personal observation) owing to some individuals becoming fluvial and moving between Beaver Creek and the Methow River.

For the climate scenarios, we used similar parameters described above with some exceptions. First, we assumed whether a fish matures or smolts would follow the environmental conditions (i.e., increased temperature) for a particular period. Thus, we updated the rules for each climate change scenario. Second, we used an earlier start date for simulations to correspond with an earlier emergence time predicted for salmonid species as stream temperatures rise (Crozier et al. 2008a; Healey 2011). To advance the date of emergence, we first calculated the degreedays (404) from spawning (May 1) to emergence (June 15) under baseline. For each climate scenario, we then recalculated emergence date assuming the same spawning date and 404 degreedays needed to emerge. However, our simulations did not start until fish were, on average, $55 \mathrm{~mm}$ (August 1 at baseline), which was 592 degree-days between emergence and August 1 under baseline. A similar approach was used to recalculate a new start date for when $55 \mathrm{~mm}$ was achieved for each climate simulation (Table 1). Third, we ran additional simulations for the climate scenarios where food quantity $\left(P_{C \max }\right)$ or quality (energy density) in the bioenergetics model were either reduced or increased at $5 \%$ increments, up to a $25 \%$ change (Table 2). We reasoned a decrease would be possible given other studies on the impacts of warming temperature on aquatic macroinvertebrates (Harper and Peckarsky 2006; Durance and Ormerod 2007; Daufresne et al. 2009). However, the Methow River basin is a coldwater, oligotrophic system (Bellmore 2011) that may experience

TABLE 2. Changes in the quality (i.e., energy density) and quantity (i.e., prey availability) of food resources in the climate scenarios. High prey availability was used for 1,700 female $O$. mykiss and low prey availability for 300 of them (see text for details).

\begin{tabular}{rccclc}
\hline & \multicolumn{2}{c}{ Energy density $(\mathrm{J} / \mathrm{g})$} & & \multicolumn{2}{c}{ Prey availability } \\
\cline { 2 - 3 } Change $(\%)$ & Terrestrial & Aquatic & & High & Low \\
\hline-25 & 3,750 & 2,100 & & 0.26 & 0.23 \\
-20 & 4,000 & 2,240 & & 0.27 & 0.24 \\
-15 & 4,250 & 2,380 & & 0.29 & 0.26 \\
-10 & 4,500 & 2,520 & & 0.31 & 0.27 \\
-5 & 4,750 & 2,660 & & 0.32 & 0.29 \\
0 & 5,000 & 2,800 & & 0.34 & 0.30 \\
5 & 5,250 & 2,940 & & 0.36 & 0.32 \\
10 & 5,500 & 3,080 & & 0.37 & 0.33 \\
15 & 5,750 & 3,220 & & 0.39 & 0.35 \\
20 & 6,000 & 3,360 & & 0.41 & 0.36 \\
25 & 6,250 & 3,500 & & 0.43 & 0.38 \\
\hline
\end{tabular}


greater primary and secondary production if temperatures increase (Woodward et al. 2010). In addition, terrestrial invertebrates provide a higher quality food resource for fish (Nakano et al. 1999), but, to our knowledge, the consequences of climate change on this subsidy have not been investigated.

\section{RESULTS}

\section{Temperature}

Average water temperature in Beaver Creek at baseline was $6.3^{\circ} \mathrm{C}$ (range $=0.7-15.2^{\circ} \mathrm{C}$ ) and increased with air temperature under each scenario modeled (Table 1). Mean water temperature increased by $10 \%$ under scenario $1\left(\right.$ mean $=6.9^{\circ} \mathrm{C}$; range $=$ $\left.0.8-15.9^{\circ} \mathrm{C}\right), 14 \%$ under scenario $2\left(7.2^{\circ} \mathrm{C} ; 0.9-16.2^{\circ} \mathrm{C}\right), 23 \%$ under scenario $3\left(7.8^{\circ} \mathrm{C} ; 1.1-16.7^{\circ} \mathrm{C}\right)$, and $42 \%$ under scenario $4\left(9.0^{\circ} \mathrm{C} ; 1.5-17.5^{\circ} \mathrm{C}\right)$. The increase in minimum water temperatures ranged from $14 \%$ to $114 \%$, whereas the increase in maximum water temperatures was more modest, ranging from $5 \%$ to $15 \%$. Increases in water temperature also varied by season, the smallest increases (8-28\%) being simulated during summer and the largest during winter (20-120\%).

\section{Baseline Model}

Most juvenile female fish under baseline temperature conditions became Steelhead smolts (59\%), the rest maturing as Rainbow Trout (41\%; Figure 2a). Overall, the state-dependent model estimated five life history trajectories under the baseline model (Figure 3a). Those that were simulated to become smolts did so at age $2(68 \%)$ and age $3(27 \%)$, the rest (5\%) doing so at age 4 (Table 3). This simulated distribution for Steelhead smolts was consistent with our field observations described above. Most of the simulated fish that matured did so at age 3, and a small fraction matured at age 4 .

Specific growth rate $\left(\mathrm{g} \cdot \mathrm{g}^{-1} \cdot \mathrm{d}^{-1}\right)$ tended to be greater and initial length $(\mathrm{mm})$ larger for females committing to a life history trajectory at a younger age (Table 3 ). For instance, fish emigrating at age 2 had a 26-33\% greater mean specific growth rate and were 9-22\% larger at the beginning of the simulation than the age- 3 and age- 4 migrants. Similar results were obtained for fish following a trajectory of freshwater maturation. Steelhead smolts and Rainbow Trout did not appear to have different specific growth rates, whereas Rainbow Trout tended to be larger at spawning than Steelhead smolts at time of migration (Figure 2).

\section{Climate Scenarios}

As water temperatures increased and food resources remained constant, our simulations suggest two notable changes in the proportion of female fish that adopted the anadromous pathway as well as the diversity of life history trajectories. First, in scenarios 1 and 2, the proportion of fish that became smolts increased from that of baseline by $50-57 \%$ (Figure $2 \mathrm{a}$ ). In addition, the number of life history trajectories declined from five

TABLE 3. Percent, mean (SD) length at the start of the simulation, mean length at emigration (smolt) or spawning (mature), and mean growth rates for each life history trajectory under the baseline and four climate scenarios (see Table 1 for climate scenario definitions).

\begin{tabular}{|c|c|c|c|c|c|c|c|c|c|}
\hline \multirow[b]{2}{*}{ Scenario } & \multirow[b]{2}{*}{ Age } & \multicolumn{2}{|c|}{ Percent } & \multicolumn{2}{|c|}{ Start length $(\mathrm{mm})$} & \multicolumn{2}{|c|}{ End length (mm) } & \multicolumn{2}{|c|}{ Growth $\left(\mathrm{g} \cdot \mathrm{g}^{-1} \cdot \mathrm{d}^{-1} \times 10^{2}\right)$} \\
\hline & & Mature & Smolt & Mature & Smolt & Mature & Smolt & Mature & Smolt \\
\hline \multirow[t]{4}{*}{ Baseline } & 1 & & & & & & & & \\
\hline & 2 & & 40.1 & & $59.3(6.6)$ & & $143.8(5.1)$ & & $0.39(0.04)$ \\
\hline & 3 & 41.0 & 15.8 & $52.3(4.7)$ & $54.2(8.0)$ & 172.5 (3.9) & $148.9(13.3)$ & $0.35(0.03)$ & $0.29(0.06)$ \\
\hline & 4 & 0.4 & 2.7 & $50.3(3.6)$ & $46.2(5.0)$ & $156.1(2.4)$ & $155.9(2.9)$ & $0.25(0.02)$ & $0.26(0.2)$ \\
\hline \multirow[t]{4}{*}{1} & 1 & & & & & & & & \\
\hline & 2 & & 80.3 & & $56.1(6.7)$ & & $151.3(5.9)$ & & $0.44(0.04)$ \\
\hline & 3 & 8.0 & 11.5 & $53.1(9.3)$ & $52.8(6.0)$ & $169.4(15.1)$ & $148.9(4.4)$ & $0.34(0.07)$ & $0.30(0.03)$ \\
\hline & 4 & 0.2 & & $40.6(2.4)$ & & $158.0(0.8)$ & & $0.29(0.01)$ & \\
\hline \multirow[t]{4}{*}{2} & 1 & & & & & & & & \\
\hline & 2 & 0.2 & 85.4 & $72.3(4.1)$ & $55.2(7.0)$ & $163.6(3.4)$ & $157.4(7.0)$ & $0.37(0.03)$ & $0.46(0.05)$ \\
\hline & 3 & 11.8 & 2.6 & $56.7(6.3)$ & $47.9(5.7)$ & $154.6(7.6)$ & $151.0(3.0)$ & $0.29(0.04)$ & $0.33(0.03)$ \\
\hline & 4 & & & & & & & & \\
\hline \multirow[t]{4}{*}{3} & 1 & & & & & & & & \\
\hline & 2 & 17.0 & 73.5 & $64.5(4.4)$ & $53.2(6.0)$ & $166.7(4.0)$ & $163.8(10.0)$ & $0.43(0.03)$ & $0.49(0.05)$ \\
\hline & 3 & 9.5 & & $56.4(6.5)$ & & $162.1(4.9)$ & & $0.31(0.03)$ & \\
\hline & 4 & & & & & & & & \\
\hline \multirow[t]{4}{*}{4} & 1 & & 4.7 & & $68.2(3.6)$ & & $133.3(2.7)$ & & $0.61(0.04)$ \\
\hline & 2 & 92.6 & 2.7 & $55.0(6.4)$ & 46.9 (4.3) & $173.9(13.0)$ & $143.4(3.7)$ & $0.52(0.06)$ & $0.48(0.04)$ \\
\hline & 3 & & & & & & & & \\
\hline & 4 & & & & & & & & \\
\hline
\end{tabular}



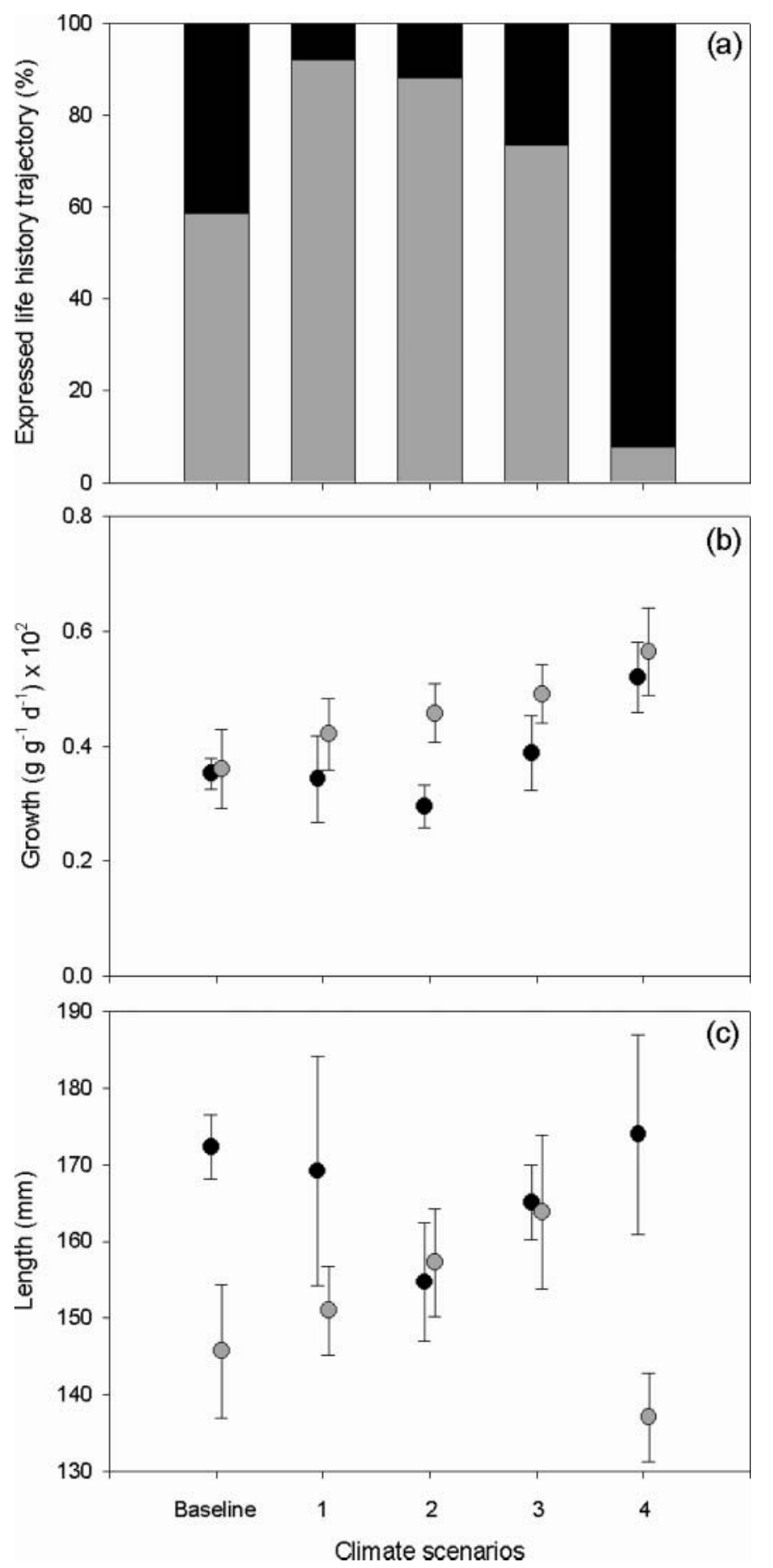

FIGURE 2. The proportion of (a) expressed life history trajectory, (b) mean specific growth rate $( \pm \mathrm{SD})$, and (c) mean fork length for resident female Rainbow Trout (black) and Steelhead smolts (gray) in Beaver Creek, Washington, under baseline and climate scenarios. Growth was averaged for each fish from emergence date to time of spawning for Rainbow Trout or emigration for Steelhead smolts, and then averaged among fish. Similarly, length was averaged among fish at time of spawning or emigration (see Table 1 for definition of climate scenarios). (a)

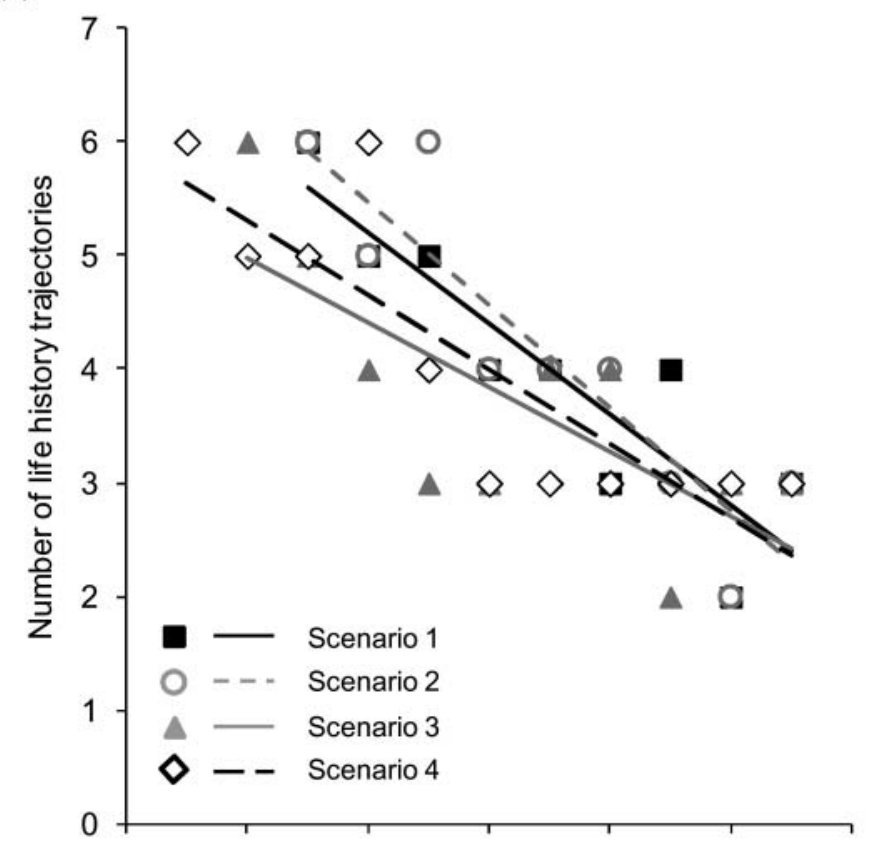

(b)

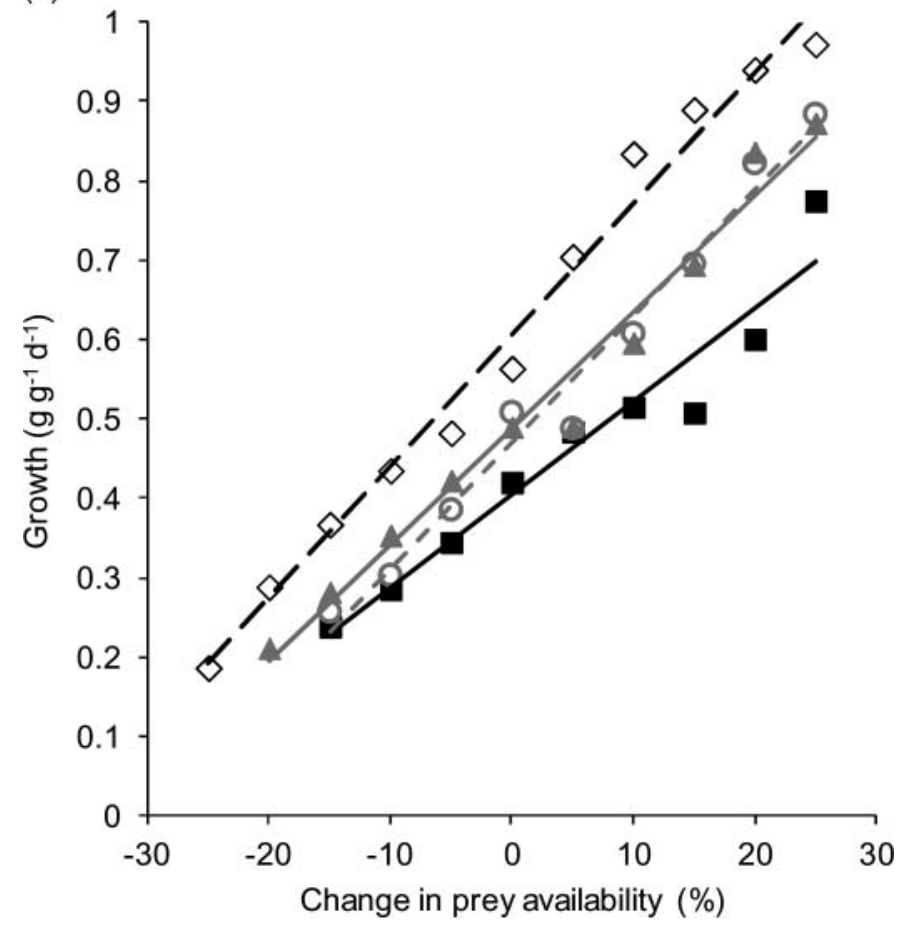

FIGURE 3. Relationship between changes in prey availability and (a) the number of life history trajectories or (b) specific growth $\left(\times 10^{2}\right)$ at different warming scenarios. Linear trend lines of life history trajectories from the simulated data have the following $r^{2}$ : scenario $1, r^{2}=0.80$; scenario $2, r^{2}=0.82$; scenario $3, r^{2}=0.55$; and scenario $4, r^{2}=0.74$. For growth, $r^{2} \geq 0.94$ (see Table 1 for definition of climate scenarios). 
in baseline to four in scenarios 1 and 2 owing to the eventual loss of those that adopted either trajectory at age 4 and the subsequent appearance of those maturing at age 2 (Table 3 ). Second, under scenario 4 , the proportion of females becoming Steelhead smolts declined up to $87 \%$ compared with baseline. Furthermore, the number of life history trajectories was reduced to three in scenarios 3 and 4 . In scenario 3, most fish (74\%) adopted an anadromous trajectory at age 2 , whereas in scenario 4, most fish (93\%) became Rainbow Trout at age 2.

In our simulations, the commitment to a life history trajectory at younger ages was because of the changes in growth and length with increasing temperature. On average, specific growth rate increased with temperature up to $57 \%$ for Steelhead smolts and $48 \%$ for Rainbow Trout (Figure 2b). However, up to a $16 \%$ decrease in growth was exhibited between baseline and scenarios 1 and 2 for Rainbow Trout owing to the slower growing fish adopting this pathway. In scenario 3, the average size of Steelhead smolts gradually increased by $11 \%$. Size of Steelhead then declined from that of baseline by $6 \%$ in scenario 4 because of more fish becoming smolts at a younger age (age 1 versus age 2; Figure 2c). In contrast, the size of spawning female Rainbow Trout declined up to $10 \%$ between baseline and scenarios 1 and 2 owing to slower growing fish adopting this pathway at a younger age. The size of age- 2 spawning Rainbow Trout in scenario 4 was similar to the size of Rainbow Trout in baseline but at a younger age.

\section{Changes in Food Quality or Quantity}

We attempted to decrease and increase prey quantity or quality up to $25 \%$ at $5 \%$ increments. However, in the life history model, if growth was restricted to the point that length thresholds would not be reached by all fish the model failed to run. This was the case for scenarios 1 and 2, where we were only able to reduce prey resources up to $-15 \%$, and $-20 \%$ for scenario 3 . Regardless, patterns were similar for reductions in prey quantity and quality; thus, we present only results from reductions in prey quantity (i.e., prey availability).

Distinct trends were apparent between food resources and warming temperatures in life history diversity, fish growth, and the proportion of individuals adopting an anadromous trajectory, whereas their length at emigration varied. Life history diversity declined with increased food quantity (Figure 3a). Moreover, at low prey availability, life history diversity appeared to be more sensitive to changes in temperature, whereas greater prey availability offset the influence of temperature. Under each climate scenario, growth of fish was positively related to food resources, warmer temperatures having greater growth across the amount of prey available (Figure 3b). Our simulations suggested a general decline in the proportion of smolts with increasing food resources. However, this was dependent on the climate scenario (Figure 4). For instance, in the two warmest climate scenarios, the lowest proportion of smolts was at intermediate to moderately high levels of food resources. This pattern was because of a shift from older age-classes (age 3 to age 7) at low food resources to younger age-classes (age 1 and age 2) at higher food resources. Length varied among climate scenarios and available food owing to fish following an anadromous or nonanadromous trajectory at a younger age as temperature and food resources increased.

\section{DISCUSSION}

In this study, we used a bioenergetics approach, coupled with a life history model, as a conceptual framework for understanding how $O$. mykiss may respond to potential increases in temperature and changes in food resources owing to climate change. Our simulations suggested that Rainbow TroutSteelhead in Beaver Creek will respond to warmer water temperatures by a decrease in size and age at maturation or age at smoltification, and a reduction in life history diversity because of a faster growth rate. Moreover, ecologically significant life history changes may occur with a small amount of warming (i.e., $\sim 0.6^{\circ} \mathrm{C}$ ), which may imply that the population in Beaver Creek is near a threshold. However, these responses may be mediated or exacerbated by concomitant changes in food resources.

The results of our simulations are consistent with some empirical evidence but run counter to the results of others. For example, increased stream temperature following logging led to faster growth, increased overwinter survival, and younger age of smoltification of Coho Salmon O. kisutch (Holtby 1988). Similarly, growth of Sockeye Salmon O. nerka in an Alaskan watershed increased with warming temperatures apparently owing to increased food availability (Schindler et al. 2005). However, other empirical evidence has shown negative (McCarthy et al. 2009) or no effects (Boughton et al. 2007) of increased temperature on the growth of juvenile Pacific salmon and Steelhead in warm water, California streams. A likely reason for the inconsistency among our simulations and some empirical evidence is because of the thermal regime of the study watershed. For example, Beer and Anderson (2011) predicted that warmer water temperatures would have a positive effect on the growth of fish in coldwater basins and a negative effect in warmwater basins. As with the other watersheds where positive effects of water temperature on fish growth were observed (e.g., Holtby 1988; Schindler et al. 2005; Woodward et al. 2010), the Methow River watershed is a coldwater basin. Based on our simulations, maximum weekly water temperatures never exceeded $18^{\circ} \mathrm{C}$, which is well below the maximum thermal limit for O. mykiss (Hokanson et al. 1977). In fact, the Methow River watershed has been identified as one of the last thermal refuges for coldwater fish in the interior Columbia River basin following climate change (Rieman et al. 2007).

Climatic conditions experienced during early development may have consequences for survival and performance later in life as observed for fish (Holtby 1988; Jonsson et al. 2005) as well as birds, mammals, and amphibians (Lindström 1999; 


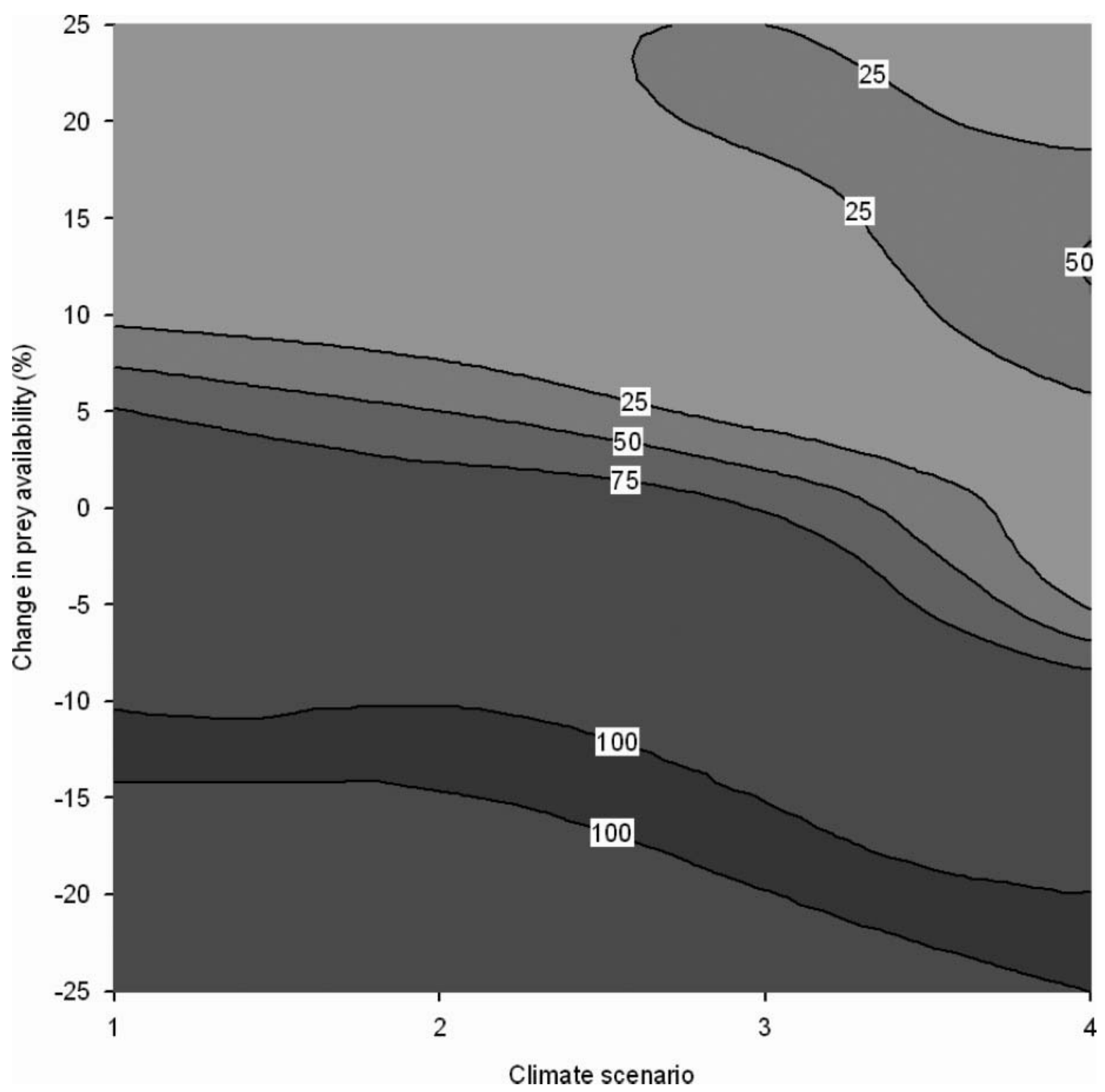

FIGURE 4. Results of model simulations identifying the proportion of female $O$. mykiss that will adopt an anadromous life history trajectory (i.e., become Steelhead smolts) under different climate scenarios and prey availability (see Table 2 for values that correspond to changes in prey availability).

Grayson et al. 2011). In Steelhead, marine survival has been observed to increase with body size (Ward and Slaney 1988) and age of smolts (Holtby 1988). Based on our simulations, it may be possible that smoltification occurs at younger ages, which may have lower marine survival. However, lower survival of younger smolts may be offset by their larger size relative to baseline in all but the warmest climate scenario.

In our simulations, we detected a positive, linear relationship between growth and the quality or quantity of aquatic and terrestrial invertebrate prey in each climate scenario. This resulted in lower diversity of life history trajectories and fewer fish adopting an anadromous life history with increasing food resources. One explanation is that as food resources within natal streams approach optimal growing conditions, the fitness benefit from remaining a resident exceeds the risk (mortality) relative to the rewards (egg production) of emigrating to richer habitat. The opposite could be said when food resources in natal streams are poor. This suggests that as climate changes, food quality and availability may be more important than temperature to the growth and trajectory of juvenile O. mykiss (Beauchamp 2009) and is consistent with laboratory and field experiments (Connolly and Petersen 2003; Boughton et al. 2007). Size and abundance of aquatic macroinvertebrate prey may be reduced with warming temperatures (Durance and Ormerod 2007; Daufresne et al. 2009) unless more light is available, which would increase basal resources for macroinvertebrates 
(Hawkins et al. 1982), or colonization of invertebrate taxa tolerant to warmer water temperatures occurs (Jacobsen et al. 1997). Given that water temperature in the Methow River basin is relatively cold and that increases with climate change may be small $\left(<3^{\circ} \mathrm{C}\right)$, it is possible that the quality or quantity (or both) of food will remain constant or increase. Regardless of the response of prey resources to climate change, fish are likely to track shifts in the prey assemblage (Woodward et al. 2010) as well as select for higher quality food resources (Marcarelli et al. 2011). More controlled experiments coupled with observational studies are needed to better understand interactions between temperature and predator-prey dynamics.

The loss of life history diversity may reduce the viability of a population (Lehman and Tilman 2000; Koellner and Schmitz 2006). For example, variation in life history trajectories (e.g., age of smolting and time spent in the ocean) has allowed Sockeye Salmon populations in Bristol Bay, Alaska, to remain viable and productive under varying climate conditions (Hilborn et al. 2003). In contrast to the Sockeye Salmon population, the population of $O$. mykiss in Beaver Creek includes anadromous individuals as well as fluvial and nonmigratory Rainbow Trout, which may further buffer the population during poor ocean conditions because their offspring are capable of adopting either an anadromous or nonanadromous life history strategy (Christie et al. 2011). Likewise, anadromous individuals may provide a buffer when freshwater conditions are not favorable. The life history trajectories of $O$. mykiss in Beaver Creek may be further diversified by the movement of juveniles from Beaver Creek to the larger main-stem Methow River several months prior to their emigration as smolts (Connolly, unpublished data). This presmolt movement may alter the subsequent longer-distance migration to the ocean. The stability and sustainability of $O$. mykiss in Beaver Creek may be influenced by the performance of these different life history types at different times. Our simulations suggest that some life history trajectories, including that of older residents and smolts, may no longer be expressed under climate change scenarios. Moreover, based on our simulations, warmer temperatures, improved food resources, or both may lead to Rainbow Trout becoming the dominant pathway. This could have management implications because this pathway is currently not listed as a species under the Endangered Species Act, whereas those following a Steelhead pathway are listed as threatened (NOAA 2008). We recommend restoration actions that may occur in Beaver Creek, the Methow River watershed, and elsewhere be focused on maintaining or enhancing diversity of $O$. mykiss and other salmon populations as opposed to actions that focus on one life history trajectory (Battin et al. 2007).

Lipid content may be an important driver in determining life history expression of fish (Jonsson and Jonsson 1993). A surplus of lipids is needed for gonadal development; thus, individuals with greater lipid content are more likely to mature in freshwater without migrating to sea. In male $O$. mykiss, lipid content was positively correlated with freshwater maturation and negatively correlated with water temperature (McMillan et al. 2012), but this relationship may be size dependent (Connolly and Petersen 2003). Lipids have been included as a parameter in similar life history models for Atlantic Salmon Salmo salar (Thorpe et al. 1998) and could be included in the model we used to simulate the trajectories adopted by $O$. mykiss. We did not collect lipid content for O. mykiss in Beaver Creek or the Methow River, but acknowledge that if it was included it may result in a different distribution of life history trajectories.

Assumptions and limitations associated with the models we used may have influenced our results. First, we assumed that the relationship between air and water temperature would be the same as climate changes, but water temperature can also be influenced by stream shading via riparian vegetation, shifts in hydrology, or anthropogenic events such as development (Nelson et al. 2009; Isaak et al. 2010). To address this assumption, we focused on a range of temperature-warming scenarios, from relatively mild to extreme, because it is uncertain which climate scenario may be most realistic in the future. Second, our model does not consider shifts in survival of $O$. mykiss associated with climate change, but reduced survival has been suggested by modeling efforts for salmon (Crozier et al. 2008b) and other aquatic species (André et al. 2010). The life history model we used has been shown to be sensitive to freshwater and marine survival (Satterthwaite et al. 2009, 2010), but we chose to keep survival constant to allow a better understanding of the consequences that warmer temperatures alone may have on life history trajectories of $O$. mykiss. Third, salmon may not adhere to the "decision windows" we assigned in the life history model, and these windows are likely to change with climate as shown for cephalopods (André et al. 2010). Fourth, density-dependent effects were not accounted for within the model but could affect life history trajectories by altering growth rates. For example, competition for food resources is known to drive density-dependent growth in juvenile salmon populations (reviewed by Grant and Imre 2005). Although density dependence was not explicitly included, varying prey availability allowed us to assess how reductions in food resources, possibly due to density dependence, influenced life history trajectories. Lastly, our models do not consider the impacts of warming temperatures beyond smolting or maturing. Most assuredly, climate change will affect the entire life cycle and changes in ocean condition, albeit difficult to predict, could be catastrophic (Zabel et al. 2006). In the end, we present the results of our climate scenario simulations as a demonstration of potential effects rather than actual predictions. Considerable uncertainty remains about the relationship between environmental conditions, climate change, life history of $O$. mykiss, and their behaviors or physiological traits (Crozier et al. 2008a).

Our modeling effort compliments others (e.g., Mangel 1994; Schindler et al. 2005; Crozier et al. 2008a, 2008b) that have explored the potential consequences climate change may have on migratory salmon. However, we add to this body of literature by being one of the first to demonstrate potential changes in life history trajectories of $O$. mykiss, an organism with various life history pathways. Our simulations suggest that biologically 
significant changes for $O$. mykiss are likely and can occur with increases in mean water temperatures just over $0.5^{\circ} \mathrm{C}$, which may not provide much time for management actions to occur. Moreover, the response of $O$. mykiss to warming temperatures may be mediated by concomitant changes in food resources. We focused on the potential changes in life history trajectories exhibited by $O$. mykiss, but we did not explore the vulnerability of the population following warmer temperatures or other climatic events. However, managers will need to consider both when prioritizing conservation efforts. Thus, we suggest broader-scale analyses need to be conducted to better understand the generality of the consequences climate change may have on fish species that display partial migration as well as more detailed studies to understand the mechanisms that influence life history expression. One approach may be to compare biological responses across many streams with contrasting climates and food resources. Alternatively, responses of populations could be compared within one stream across years that have differing environmental conditions.

\section{ACKNOWLEDGMENTS}

We thank Grace Eger, Teresa Fish, Brian Fisher, Kyle Koger, Kyle Martens, and Wesley Tibbits for data collection that made our modeling efforts possible. Ryan Bellmore, Jason Dunham, Jeff Falke, Dan Isaak, Alec Maule, William Satterthwaite, and two anonymous reviewers provided valuable discussions or comments (or both) on earlier versions that greatly improved this manuscript. Funding was provided by the U.S. Geological Survey, U.S. Forest Service, and Bureau of Reclamation. Reference to trade names does not imply endorsement by the U.S. Government.

\section{REFERENCES}

Achord, S., R. W. Zabel, and B. P. Sandford. 2007. Migration timing, growth, and estimated parr-to-smolt survival rates of wild Snake River spring-summer Chinook salmon from the Salmon River basin, Idaho, to the lower Snake River. Transactions of the American Fisheries Society 136:142-154.

André, J., M. Haddon, and G. T. Pecl. 2010. Modelling climate-change-induced nonlinear thresholds in cephalopod population dynamics. Global Change Biology 16:2866-2875.

Battin, J., M. W. Wiley, M. H. Ruckelshaus, R. N. Palmer, E. Korb, K. K. Bartz, and H. Imaki. 2007. Projected impacts of climate change on salmon habitat restoration. Proceedings of the National Academy of Sciences of the USA 104:6720-6725.

Beauchamp, D. A. 2009. Bioenergetic ontogeny: linking climate and massspecific feeding to life-cycle growth and survival of salmon. Pages 53-71 in C. C. Krueger and C. E. Zimmerman, editors. Pacific salmon: ecology and management of western Alaska's populations. American Fisheries Society, Symposium 70, Bethesda, Maryland.

Beer, W. N., and J. J. Anderson. 2011. Sensitivity of juvenile salmonid growth to future climate trends. River Research and Applications 27:663-669.

Bellmore, J. R. 2011. The ecological importance of floodplains in montane river networks: implications for habitat restoration and salmon recovery. Doctoral dissertation. Idaho State University, Pocatello.

Berejikian, B. A., D. A. Larsen, P. Swanson, M. E. Moore, C. P. Tatara, W. L. Gale, C. R. Pasley, and B. R. Beckman. 2012. Development of natural growth regimes for hatchery-reared steelhead to reduce residualism, fitness loss, and negative ecological interactions. Environmental Biology of Fishes 94:29-44.
Boughton, D. A., M. Gibson, R. Yedor, and E. Kelley. 2007. Stream temperature and the potential growth and survival of juvenile Oncorhynchus mykiss in a southern California creek. Freshwater Biology 52:1353-1364.

Bradford, M. J. 1995. Comparative review of Pacific salmon survival rates. Canadian Journal of Fisheries and Aquatic Sciences 52:1327-1338.

Brander, K. M. 2007. Global fish production and climate change. Proceedings of the National Academy of Sciences of the USA 104:19709-19714.

Christie, M. R., M. L. Marine, and M. S. Blouin. 2011. Who are the missing parents? grandparentage analysis identifies multiple sources of gene flow into a wild population. Molecular Ecology 20:1263-1276.

Connolly, P. J., I. G. Jezorek, K. D. Martens, and E. F. Prentice. 2008. Measuring the performance of two stationary interrogation systems for detecting downstream and upstream movement of PIT-tagged salmonids. North American Journal of Fisheries Management 28:402-417.

Connolly, P. J., and J. H. Petersen. 2003. Bigger is not always better for overwintering young-of-year steelhead. Transactions of the American Fisheries Society 132:262-274.

Cotton, P. A. 2003. Avian migration phenology and global climate change. Proceedings of the National Academy of Sciences of the USA 100:1221912222.

Crozier, L. G., A. P. Hendry, P. W. Lawson, T. P. Quinn, N. J. Mantua, J. Battin, R. G. Shaw, and R. B. Huey. 2008a. Potential responses to climate change in organisms with complex life histories: evolution and plasticity in Pacific salmon. Evolutionary Applications 1:252-270.

Crozier, L. G., R. W. Zabel, and A. F. Hamlet. 2008b. Predicting differential effects of climate change at the population level with life-cycle models of spring Chinook salmon. Global Change Biology 14:236-249.

Daufresne, M., K. Lengfellner, and U. Sommer. 2009. Global warming benefits the small in aquatic ecosystems. Proceedings of the National Academy of Sciences of the USA 106:12788-12793.

Durance, I., and S. J. Ormerod. 2007. Climate change effects on upland stream macroinvertebrates over a 25-year period. Global Change Biology 13:942957.

Eaton, J. G., and R. M. Scheller. 1996. Effects of climate warming on fish thermal habitat in streams of the United States. Limnology and Oceanography 41:1109-1115.

Gale, W. L., C. R. Pasley, B. M. Kennedy, and K. G. Ostrand. 2009. Juvenile steelhead release strategies: a comparison of volitional- and forced-release practices. North American Journal of Aquaculture 71:97-106.

Grant, J. W. A., and I. Imre. 2005. Patterns of density-dependent growth in juvenile stream-dwelling salmonids. Journal of Fish Biology 67(Supplement B):100-110.

Grayson, K. L., L. L. Bailey, and H. M. Wilbur. 2011. Life history benefits of residency in a partially migrating pond-breeding amphibian. Ecology 92:1236-1246.

Hanson, P. C., T. B. Johnson, D. E. Schindler, and J. F. Kitchell. 1997. Fish bioenergetics 3.0 software for Windows ${ }^{\circledR}$. University of Wisconsin-Madison, Center for Limnology, University of Wisconsin Sea Grant Institute, WISCUT-97-001, Madison.

Harper, M. P., and B. L. Peckarsky. 2006. Emergence cues of a mayfly in a highaltitude stream ecosystem: potential response to climate change. Ecological Applications 16:612-621.

Hawkins, C. P., M. L. Murphy, and N. H. Anderson. 1982. Effects of canopy, substrate composition, and gradient on the structure of macroinvertebrate communities in Cascade Range streams of Oregon. Ecology 63:18401856.

Healey, M. 2011. The cumulative impacts of climate change on Fraser River sockeye salmon (Oncorhynchus nerka) and implications for management. Canadian Journal of Fisheries and Aquatic Sciences 68:718-737.

Hilborn, R., T. P. Quinn, D. E. Schindler, and D. E. Rogers. 2003. Biocomplexity and fisheries sustainability. Proceedings of the National Academy of Sciences of the USA 100:6564-6568.

Hodge, B. 2010. Life history variation in Oncorhynchus mykiss from the Klamath River basin. Master's thesis. Humboldt State University, Arcata, California. 
Hokanson, K. E. F., C. F. Kleiner, and T. W. Thorslund. 1977. Effects of constant temperatures and diel temperature fluctuations on specific growth and mortality rates and yield of juvenile rainbow trout, Salmo gairdneri. Journal of the Fisheries Research Board of Canada 34:639-648.

Holtby, L. B. 1988. Effects of logging on stream temperatures in Carnation Creek, British Columbia, and associated impacts on the coho salmon (Oncorhynchus kisutch). Canadian Journal of Fisheries and Aquatic Sciences 45:502-515.

IPCC (Intergovernmental Panel on Climate Change). 2007. Climate change 2007: the physical science basis. IPCC, Geneva, Switzerland. Available: www.ipcc.ch. (January 2012).

Isaak, D. J., C. H. Luce, B. E. Rieman, D. E. Nagel, E. E. Peterson, D. L. Horan, S. Parkes, and G. L. Chandler. 2010. Effects of climate change and wildfire on stream temperatures and salmonid thermal habitat in a mountain river network. Ecological Applications 20:1350-1371.

Jacobsen, D., R. Schultz, and A. Encalada. 1997. Structure and diversity of stream invertebrate assemblages: the influence of temperature with altitude and latitude. Freshwater Biology 38:247-261.

Jonsson, B., and N. Jonsson. 1993. Partial migration: niche shift versus sexual maturation in fishes. Reviews in Fish Biology and Fisheries 3:348-365.

Jonsson, B., and N. Jonsson. 2009. A review of the likely effects of climate change on anadromous Atlantic salmon Salmo salar and brown trout Salmo trutta, with particular reference to water temperature and flow. Journal of Fish Biology 75:2381-2447.

Jonsson, N., B. Jonsson, and L. P. Hansen. 2005. Does climate during embryonic development influence parr growth and age of seaward migration in Atlantic salmon (Salmo salar)? Canadian Journal of Fisheries and Aquatic Sciences 62:2502-2508.

Koellner, T., and O. J. Schmitz. 2006. Biodiversity, ecosystem function, and investment risk. BioScience 56:977-985.

Lehman, C. L., and D. Tilman. 2000. Biodiversity, stability, and productivity in competitive communities. American Naturalist 156:534-552.

Lindström, J. 1999. Early development and fitness in birds and mammals. Trends in Ecology and Evolution 14:343-348.

Mangel, M. 1994. Climate change and salmonid life history variation. Deep-Sea Research, Part II 41:75-106.

Marcarelli, A. M., C. V. Baxter, M. M. Mineau, and R. O. Hall Jr. 2011. Quantity and quality: unifying food web and ecosystem perspectives on the role of resource subsidies in freshwaters. Ecology 92:1215-1225.

Martens, K. D., and P. J. Connolly. 2010. Effectiveness of a redesigned water diversion using rock vortex weirs to enhance longitudinal connectivity for small salmonids. North American Journal of Fisheries Management 30:1544 1552.

McCarthy, S. G., J. J. Duda, J. M. Emlen, G. R. Hodgson, and D. A. Beauchamp. 2009. Linking habitat quality with trophic performance of steelhead along forest gradients in the South Fork Trinity River watershed, California. Transactions of the American Fisheries Society 138:506-521.

McMillan, J. R., J. B. Dunham, G. H. Reeves, J. S. Mills, and C. E. Jordan. 2012. Individual condition and stream temperature influence early maturation of rainbow and steelhead trout, Oncorhynchus mykiss. Environmental Biology of Fishes 93:343-355.

Mohseni, O., and H. G. Stefan. 1999. Stream temperature/air temperature relationship: a physical interpretation. Journal of Hydrology 218:128-141.

Mohseni, O., H. G. Stefan, and T. R. Erickson. 1998. A nonlinear regression model for weekly stream temperatures. Water Resources Research 34:26852692.

Morinville, G. R., and J. B. Rasmussen. 2003. Early juvenile bioenergetic differences between anadromous and resident brook trout (Salvelinus fontinalis). Canadian Journal of Fisheries and Aquatic Sciences 60:401-410.

Mote, P. W., and E. P. Salathé Jr. 2010. Future climate in the Pacific Northwest. Climatic Change 102:29-50.

Nakano, S., H. Miyasaka, and N. Kuhara. 1999. Terrestrial-aquatic linkages: riparian arthropod inputs alter trophic cascades in a stream food web. Ecology 80:2435-2441.
Nash, J. E., and J. V. Sutcliffe. 1970. River flow forecasting through conceptual models part I: a discussion of principles. Journal of Hydrology 10:282-290.

Nelson, K. C., M. A. Palmer, J. E. Pizzuto, G. E. Moglen, P. L. Angermeier, R. H. Hilderbrand, M. Dettinger, and K. Hayhoe. 2009. Forecasting the combined effects of urbanization and climate change on stream ecosystems: from impacts to management options. Journal of Applied Ecology 46:154163.

Nemani, R. R., C. D. Keeling, H. Hashimoto, W. M. Jolly, S. C. Piper, C. J. Tucker, R. B. Myneni, and S. W. Running. 2003. Climate-driven increases in global terrestrial net primary production from 1982 to 1999 . Science 300:1560-1563.

NOAA (National Oceanic and Atmospheric Administration). 2008. ESA salmon listings. NOAA, National Marine Fisheries Service, Northwest Regional Office, Seattle. Available: www.nwr.noaa.gov/ESA-Salmon-Listings/SalmonPopulations/Reports-and-Publications/Index.cfm. (January 2012).

Olsson, I. C., L. A. Greenberg, E. Bergman, and K. Wysujack. 2006. Environmentally induced migration: the importance of food. Ecology Letters 9:645-651.

Peven, C. M., R. R. Whitney, and K. R. Williams. 1994. Age and length of steelhead smolts from the mid-Columbia River basin, Washington. North American Journal of Fisheries Management 14:77-86.

Pörtner, H. O., and A. P. Farrell. 2008. Physiology and climate change. Science 322:690-692.

R Development Core Team. 2011. R: a language and environment for statistical computing. R Foundation for Statistical Computing, Vienna. Available: www.R-project.org. (January 2012).

Railsback, S. F., and K. A. Rose. 1999. Bioenergetics modeling of stream trout growth: temperature and food consumption effects. Transactions of the American Fisheries Society 128:241-256.

Rieman, B. E., D. Isaak, S. Adams, D. Horan, D. Nagel, C. Luce, and D. Myers. 2007. Anticipated climate warming effects on bull trout habitats and populations across the interior Columbia River basin. Transactions of the American Fisheries Society 136:1552-1565.

Roy, D. B., and T. H. Sparks. 2000. Phenology of British butterflies and climate change. Global Change Biology 6:407-416.

Satterthwaite, W. H., M. P. Beakes, E. M. Collins, D. R. Swank, J. E. Merz, R. G. Titus, S. M. Sogard, and M. Mangel. 2009. Steelhead life history on California's central coast: insights from a state-dependent model. Transactions of the American Fisheries Society 138:532-548.

Satterthwaite, W. H., M. P. Beakes, E. M. Collins, D. R. Swank, J. E. Merz, R. G. Titus, S. M. Sogard, and M. Mangel. 2010. State-dependent life history models in a changing (and regulated) environment: steelhead in the California Central Valley. Evolutionary Applications 3:221-243.

Schindler, D. E., D. E. Rogers, M. D. Scheuerell, and C. A. Abrey. 2005. Effects of changing climate on zooplankton and juvenile sockeye salmon growth in southwestern Alaska. Ecology 86:198-209.

Snow, C., C. Frady, A. Fowler, and A. Murdoch. 2008. Monitoring and evaluation of Wells and Methow hatchery programs in 2007. Washington Department of Fish and Wildlife, Report to Douglas County Public Utility District, Olympia.

Thornton, K. W., and A. S. Lessem. 1978. A temperature algorithm for modifying biological rates. Transactions of the American Fisheries Society 107:284287.

Thorpe, J. E. 2007. Maturation responses of salmonids to changing developmental opportunities. Marine Ecology Progress Series 335:285-288.

Thorpe, J. E., M. Mangel, N. B. Metcalfe, and F. A. Huntingford. 1998. Modelling the proximate basis of salmonid life-history variation, with application to Atlantic salmon, Salmo salar L. Evolutionary Ecology 12:581-599.

Ward, B. R., and P. A. Slaney. 1988. Life history and smolt-to-adult survival of Keogh River steelhead trout (Salmo gairdneri) and the relationship to smolt size. Canadian Journal of Fisheries and Aquatic Sciences 45:1110-1122.

Ward, B. R., and P. A. Slaney. 1993. Egg-to-smolt survival and fry-to-smolt density dependence of Keogh River steelhead trout. Canadian Special Publication of Fisheries and Aquatic Sciences 118:209-217. 
Ward, B. R., P. A. Slaney, A. R. Facchin, and R. W. Land. 1989. Size-based survival in steelhead trout (Oncorhynchus mykiss): back-calculated lengths from adults' scales compared to migrating smolts at the Keogh River, British Columbia. Canadian Journal of Fisheries and Aquatic Sciences 46:18531858.

Woodward, G., J. B. Dybkjær, J. S. Ólafsson, G. M. Gíslason, E. R. Hannesdóttir, and N. Friberg. 2010. Sentinel systems on the razor's edge: effects of warming on Arctic geothermal stream ecosystems. Global Change Biology 16:19791991.
Zabel, R. W., M. D. Scheuerell, M. M. McClure, and J. G. Williams. 2006. The interplay between climate variability and density dependence in the population viability of Chinook salmon. Conservation Biology 20:190200.

Zimmerman, C. E., and G. H. Reeves. 2000. Population structure of sympatric anadromous and nonanadromous Oncorhynchus mykiss: evidence from spawning surveys and otolith microchemisty. Canadian Journal of Fisheries and Aquatic Sciences 57:2152-2162. 